medRxiv preprint doi: https://doi.org/10.1101/2021.01.15.21249810; this version posted January 16, 2021. The copyright holder for this preprint (which was not certified by peer review) is the author/funder, who has granted medRxiv a license to display the preprint in perpetuity.

All rights reserved. No reuse allowed without permission.

\title{
SARS-CoV-2 seropositivity and seroconversion in patients undergoing active cancer- directed therapy
}

\section{Running Head: SARS-CoV-2 seropositivity in patients with cancer}

Lova Sun MD로 Sanjna Surya BS ${ }^{1}$, Noah G. Goodman MPH ${ }^{1}$, Anh N. Le BS ${ }^{1}$, Gregory Kelly MS ${ }^{1}$, Olutosin Owoyemi BS ${ }^{1}$, Heena Desai MS ${ }^{1}$, Cathy Zheng BS ${ }^{1}$, Shannon DeLuca BS ${ }^{1}$, Madeline L. Good BS ${ }^{1}$, Jasmin Hussain BS ${ }^{2}$, Seth D. Jeffries BS ${ }^{1}$, Yolanda R. Kry BS², Emily M. Kugler BS ${ }^{1}$, Maikel Mansour MPH${ }^{2}$, John Ndicu AS ${ }^{1}$, AnnaClaire Osei-Akoto BA $^{3}$, Timothy Prior BS ${ }^{2}$, Stacy L. Pundock BA ${ }^{1}$, Lisa A. Varughese PharmD ${ }^{3}$, JoEllen Weaver $\mathrm{BS}^{3}$, Abigail Doucette $\mathrm{MPH}^{4}$, Scott Dudek BA ${ }^{3}$, Shefali Setia Verma $\mathrm{MS}^{3}$, Sigrid Gouma PhD ${ }^{5}$, Madison E. Weirick BS ${ }^{5}$, Christopher M. McAllister BS ${ }^{5}$, Erin Bange MD $^{1}$, Peter Gabriel MD ${ }^{4,6}$, Marylyn Ritchie PhD $^{3}$, Daniel J. Rader $\mathrm{MD}^{3}$, Robert $\mathrm{H}$. Vonderheide MD DPhil ${ }^{1,6}$, Lynn M Schuchter $\mathrm{MD}^{1,6}$, Anurag Verma $\mathrm{PhD}^{3}$, Ivan Maillard MD PhD ${ }^{1,6}$, Ronac Mamtani MD MSCE${ }^{1,6}$, Scott E. Hensley PhD ${ }^{5}$, Robert Gross MD $\mathrm{MSCE}^{7}$, E. Paul Wileyto $\mathrm{PhD}^{8}$, Alexander C. Huang MD ${ }^{1,6}$, Kara N. Maxwell MD PhD ${ }^{1,3,6^{*}}$, Angela DeMichele MD MSCE ${ }^{1,6^{*}}$

1. Division of Hematology/Oncology, Department of Medicine, Perelman School of Medicine at the University of Pennsylvania, Philadelphia, PA, 19104

2. Department of Neurosurgery, Perelman School of Medicine at the University of Pennsylvania, Philadelphia, PA, 19104

3. Department of Genetics, Perelman School of Medicine at the University of Pennsylvania, Philadelphia, PA, 19104

4. Department of Radiation Oncology, Perelman School of Medicine at the University of Pennsylvania, Philadelphia, PA, 19104

5. Department of Microbiology, University of Pennsylvania, Philadelphia, PA, 19104

6. Abramson Cancer Center, University of Pennsylvania, Philadelphia, PA, 19104

7. Department of Medicine, Perelman School of Medicine at the University of Pennsylvania, Philadelphia, PA, 19104

8. Department of Biostatistics, Epidemiology, and Informatics, Perelman School of Medicine at the University of Pennsylvania, Philadelphia, PA, 19104

*These last authors equally contributed to this manuscript

Correspondence to: Angela DeMichele, MD MSCE, Division of Hematology/Oncology, Department of Medicine, 3400 Civic Center Blvd, PCAM 10-South, Philadelphia, PA 19104, USA; P: 215.349.5730 I Fax: 215.615.3349 | Email:

angela.demichele@pennmedicine.upenn.edu

\section{Funding:}

This work was supported by the National Institutes of Health (P30-CA016520 to Abramson Cancer Center and RHV), a gift from the Smilow family, the National Center for Advancing Translational Sciences of the National Institutes of Health under CT6SA Award Number UL1TR001878, the Tara Miller Melanoma Excellence Fund, and the Perelman School of Medicine at the University of Pennsylvania. J. Lurie, J. Embiid, J. Harris, and D. Blitzer provided philanthropic support that was critical for establishing the serological assays used in this study.

Key Words: COVID-19 antibody testing, SARS-CoV-2, seropositivity, seroconversion, transmission mitigation 
medRxiv preprint doi: https://doi.org/10.1101/2021.01.15.21249810; this version posted January 16, 2021. The copyright holder for this preprint (which was not certified by peer review) is the author/funder, who has granted medRxiv a license to display the preprint in perpetuity.

All rights reserved. No reuse allowed without permission.

\section{Abstract}

Multiple studies have demonstrated the negative impact of cancer care delays during the COVID-19 pandemic, and transmission mitigation techniques are imperative for continued cancer care delivery. To gauge the effectiveness of these measures at the University of Pennsylvania, we conducted a longitudinal study of SARS-CoV-2 antibody seropositivity and seroconversion in patients presenting to infusion centers for cancer-directed therapy between 5/21/2020 and 10/8/2020. Participants completed questionnaires and had up to five serial blood collections. Of 124 enrolled patients, only two (1.6\%) had detectable SARS-CoV-2 antibodies on initial blood draw, and no initially seronegative patients developed newly detectable antibodies on subsequent blood draw(s), corresponding to a seroconversion rate of $0 \%(95 \% \mathrm{Cl} 0.0-4.1 \%)$ over 14.8 person-years of follow up, with a median of 13 healthcare visits per patient. These results suggest that cancer patients receiving in-person care at a facility with aggressive mitigation efforts have an extremely low likelihood of COVID-19 infection. 
medRxiv preprint doi: https://doi.org/10.1101/2021.01.15.21249810; this version posted January 16, 2021. The copyright holder for this preprint (which was not certified by peer review) is the author/funder, who has granted medRxiv a license to display the preprint in perpetuity.

All rights reserved. No reuse allowed without permission.

\section{Introduction}

Patients with cancer are at risk for poor outcomes with COVID-19[1-9]. In order to reduce person-to-person contact, a wide array of cancer care procedures have been altered or delayed during the pandemic[10, 11]. However, these disruptions are projected to lead to almost 10,000 excess deaths over the next decade from breast and colorectal cancer alone[12, 13] - a grim second public health crisis arising as a consequence of the pandemic. Patients with cancer face difficult decisions between continuing cancer-directed care and avoiding healthcare settings to decrease infection risk.

The clear need to continue delivering cancer care while minimizing risk of SARS-CoV-2 infection has highlighted the importance of transmission mitigation techniques in both healthcare and community settings. At outpatient oncology clinics at the University of Pennsylvania (Penn), efforts to reduce in-person patient volume, including virtual visits, at-home infusions, and decreased infusion frequencies, began in mid-March, 2020. For oncology patients who continued to receive in-person care, safety measures included text message questionnaires regarding contact with COVID-positive individuals, temperature screenings, contactless check-in procedures, visitor limitations, and physically separated COVID-19+ clinic spaces.

\section{Methods}

In order to gauge the effectiveness of these measures, we conducted a prospective longitudinal study to assess the rate of SARS-CoV-2 antibody seropositivity and seroconversion in patients undergoing active cancer therapy. Patients with solid malignancies presenting to the Penn Abramson Cancer Center for chemotherapy and/or immunotherapy were enrolled between 5/21/2020 and 10/8/2020. Patients were approached via phone and provided electronic consent for blood collection, electronic surveys, and access to electronic health records (EHR). We targeted patients receiving therapy on a single day of the week to capture a mixture of solid malignancy types and facilitate longitudinal follow-up. 
medRxiv preprint doi: https://doi.org/10.1101/2021.01.15.21249810; this version posted January 16, 2021. The copyright holder for this preprint (which was not certified by peer review) is the author/funder, who has granted medRxiv a license to display the preprint in perpetuity.

All rights reserved. No reuse allowed without permission.

In order to assess seropositivity and seroconversion, up to five serial blood draws were performed during treatment visits at a minimum of three weeks apart. At each encounter, $50 \mathrm{~mL}$ of blood was drawn and centrifuged for 15 minutes; serum, plasma and buffy coat were stored at -80C. Samples were assayed for SARS-CoV-2 IgG and IgM antibodies to the spike receptor binding domain antigen using an enzyme-linked immunosorbent assay (ELISA) approach, with high sensitivity and specificity[14]. Patients received electronic questionnaires at each of their blood draw dates which assessed self-reported measures of health, SARS-COV-2 exposure, and social interactions. Patients were not informed of antibody test results. This study was approved by the institutional review board at Penn.

\section{Results}

Of 440 eligible patients approached, 124 (28\%) consented and had antibody testing. The remainder either could not be reached $(n=89,28 \%)$ or declined participation $(n=227,72 \%)$. Most enrolled patients had metastatic cancer, with a median of two prior lines of systemic therapy; approximately half had ECOG performance status $>0$; and over a third were leukopenic over the course of the study (Table 1). Patients had a median of 13 (IQR 9-18) in-person healthcare visits and seven (IQR 5-10) cycles of cancer therapy from March to final study blood draw, based on EHR review. Of patients who completed the initial questionnaire, 110/121 (94\%) reported being highly compliant (4-5 on Likert scale) with CDC-recommended social distancing measures, and 81/118 (69\%) reported a low level of social interactions (going out $\leq 3$ times a week) (Supplemental Table 1). Seventy-eight patients completed $\geq 1$ subsequent survey; the majority maintained low level of social interactions (57\%) or decreased their interactions to $\leq 3$ times per week (19\%) (Supplemental Table 2). Most patients reported no exposures to individuals known or suspected to have SARS-CoV-2 infection on initial $(n=102,85 \%)$ and subsequent surveys ( $n=66,85 \%)$.

Of 124 patients enrolled, 90 had at least one subsequent blood draw, a median of 28 days apart, comprising 14.9 person-years of follow up (Figure 1). Only two (1.6\%) participants 
medRxiv preprint doi: https://doi.org/10.1101/2021.01.15.21249810; this version posted January 16, 2021. The copyright holder for this preprint (which was not certified by peer review) is the author/funder, who has granted medRxiv a license to display the preprint in perpetuity.

All rights reserved. No reuse allowed without permission.

had detectable antibodies to SARS-CoV-2 on their first blood draw. Both of these patients were female, white, and receiving chemotherapy for metastatic cancer. One patient with breast cancer had symptomatic COVID-19 in April and had only detectable IgG on her two on-study blood draws (8/27 and 9/24). The other patient, with esophageal cancer, had only detectable IgM on her two blood draws (8/20 and 9/17) and never developed symptomatic COVID-19. Of 88 seronegative patients with at least one subsequent blood draw, none developed detectable antibodies to SARS-CoV-2 on any subsequent blood draw, corresponding to a seroconversion rate of $0 \%(95 \% \mathrm{Cl} 0-4.1 \%)$ over 14.8 person-years of follow up.

\section{Discussion and Conclusion}

In this single-center prospective study, we found a low rate of seropositivity and no seroconversions in patients interacting frequently with the healthcare system in-person to receive active cancer-directed therapy. Other reports of SARS-CoV-2 seroprevalence in cancer patients have ranged from $3.6 \%[15]$ to $31.4 \%[16]$. These reports dated from periods and locations when population estimates were higher than that in Philadelphia during the study period; the non-cancer US population had an estimated seroprevalence $<10 \%$ in the majority of jurisdictions studied from August-September 2020[17]. However, a study of parturient women giving birth at two Philadelphia hospitals from April-June 2020 reported a higher $6.2 \%$ seroprevalence rate[14].

Serologic assays are imperfect measures of SARS-CoV-2 exposure and infection due to variable test sensitivity, timing, and antibody persistence[18, 19]. In particular, patients with less severe illness, as well as cancer patients on cytotoxic or immunomodulatory therapy, may have lower SARS-CoV-2 antibody levels and detection rates[20, 21]. Moreover, seroprevalence rates are a product of multiple demographic, geographic, temporal, and behavioral factors, and thus it is not possible to determine the precise causal relationship between health system mitigation strategies and seroconversion without a randomized trial. Questionnaire responses showed that our patients were generally highly adherent to COVID-19 prevention strategies, potentially due 
medRxiv preprint doi: https://doi.org/10.1101/2021.01.15.21249810; this version posted January 16, 2021. The copyright holder for this preprint (which was not certified by peer review) is the author/funder, who has granted medRxiv a license to display the preprint in perpetuity.

All rights reserved. No reuse allowed without permission.

to a personal sense of vulnerability. However, the low rate of SARS-CoV-2 seropositivity and seroconversion seen in our cohort likely also reflects the success of transmission mitigation measures within healthcare facilities, and suggests that these efforts, when combined with social distancing outside the healthcare setting, may help protect vulnerable cancer patients from SARS-CoV-2 exposure and infection, even when ongoing immunomodulatory cancer treatments and frequent healthcare exposure are necessary. Continued reinforcement of practices including physical distancing, masking, and visitor limitation will remain critical as pandemic fatigue rises along with COVID-19 cases.

Acknowledgements: We acknowledge the Penn Medicine BioBank (PMBB) for providing data and thank the patient-participants of Penn Medicine who consented to participate in this research program. The PMBB is approved under IRB protocol \#813913.

Author Disclosures: RHV reports having received consulting fees or honoraria from Medimmune and Verastem; and research funding from Fibrogen, Janssen, and Lilly. He is a member of the Lustgarten Therapeutics Advisory working group. He is an inventor on a licensed patents relating to cancer cellular immunotherapy and cancer vaccines, and receives royalties from Children's Hospital Boston for a licensed research-only monoclonal antibody. SEH has received consultancy fee from Sanofi Pasteur, Lumen, Novavax, and Merck for work unrelated to this report. Other authors declare that they have no competing interests. 


\section{References}

1 Meng Y, Lu W, Guo E, et al. Cancer history is an independent risk factor for mortality in hospitalized covid-19 patients: A propensity score-matched analysis. J Hematol Oncol 2020;13:75.

2 Ma J, Yin J, Qian Y, et al. Clinical characteristics and prognosis in cancer patients with covid-19: A single center's retrospective study. J Infect 2020;81:318-356.

3 Mehta V, Goel S, Kabarriti R, et al. Case fatality rate of cancer patients with covid-19 in a new york hospital system. Cancer Discov 2020;10:935-941.

4 Dai M, Liu D, Liu M, et al. Patients with cancer appear more vulnerable to sars-cov-2: A multicenter study during the covid-19 outbreak. Cancer Discov 2020;10:783-791.

5 Liang W, Guan W, Chen R, et al. Cancer patients in sars-cov-2 infection: A nationwide analysis in china. The Lancet Oncology 2020;21:335-337.

6 Zhang L, Zhu F, Xie L, et al. Clinical characteristics of covid-19-infected cancer patients: A retrospective case study in three hospitals within wuhan, china. Annals of oncology : official journal of the European Society for Medical Oncology 2020

7 Miyashita $\mathrm{H}$, Mikami T, Chopra N, et al. Do patients with cancer have a poorer prognosis of covid-19? An experience in new york city. Annals of oncology : official journal of the European Society for Medical Oncology 2020;31:1088-1089.

8 Yang K, Sheng Y, Huang C, et al. Clinical characteristics, outcomes, and risk factors for mortality in patients with cancer and covid-19 in hubei, china: A multicentre, retrospective, cohort study. The Lancet Oncology 2020;21:904-913.

9 Rugge M, Zorzi M, Guzzinati S. Sars-cov-2 infection in the italian veneto region: Adverse outcomes in patients with cancer. Nature Cancer 2020;1:784-788.

10 Broom A, Kenny K, Page A, et al. The paradoxical effects of covid-19 on cancer care: Current context and potential lasting impacts. Clinical Cancer Research 2020 
medRxiv preprint doi: https://doi.org/10.1101/2021.01.15.21249810; this version posted January 16, 2021. The copyright holder for this preprint (which was not certified by peer review) is the author/funder, who has granted medRxiv a license to display the preprint in perpetuity.

All rights reserved. No reuse allowed without permission.

11 Richards $\mathrm{M}$, Anderson $\mathrm{M}$, Carter $\mathrm{P}$, et al. The impact of the covid-19 pandemic on cancer care. Nature Cancer 2020;1:565-567.

12 Sharpless NE. Covid-19 and cancer. Science 2020;368:1290.

13 Jazieh AR, Akbulut $\mathrm{H}$, Curigliano $\mathrm{G}$, et al. Impact of the covid-19 pandemic on cancer care: A global collaborative study. JCO Global Oncology 2020:1428-1438.

14 Flannery DD, Gouma S, Dhudasia MB, et al. Sars-cov-2 seroprevalence among parturient women in philadelphia. Sci Immunol 2020;5:eabd5709.

15 Fuereder T, Berghoff AS, Heller G, et al. Sars-cov-2 seroprevalence in oncology healthcare professionals and patients with cancer at a tertiary care centre during the covid-19 pandemic. ESMO Open 2020;5:e000889.

16 Cabezón-Gutiérrez L, Custodio-Cabello S, Palka-Kotlowska M, et al. Seroprevalence of sars-cov-2-specific antibodies in cancer outpatients in madrid (spain): A single center, prospective, cohort study and a review of available data. Cancer Treat Rev 2020;90:102102.

17 Bajema KL, Wiegand RE, Cuffe K, et al. Estimated sars-cov-2 seroprevalence in the us as of september 2020. JAMA internal medicine 2020

18 Burgess S, Ponsford MJ, Gill D. Are we underestimating seroprevalence of sars-cov-2? BMJ 2020;370:m3364.

19 Gill D and Ponsford MJ. Testing for antibodies to sars-cov-2. BMJ 2020;371:m4288.

20 Solodky ML, Galvez C, Russias B, et al. Lower detection rates of sars-cov2 antibodies in cancer patients versus health care workers after symptomatic covid-19. Annals of Oncology 2020;31:1087-1088.

21 Bi J, Lin Y, Zhong R, et al. Prevalence and clinical characterization of cancer patients with asymptomatic sars-cov-2 infection history. The Journal of infection 2020:S01634453(0120)30493-X. 


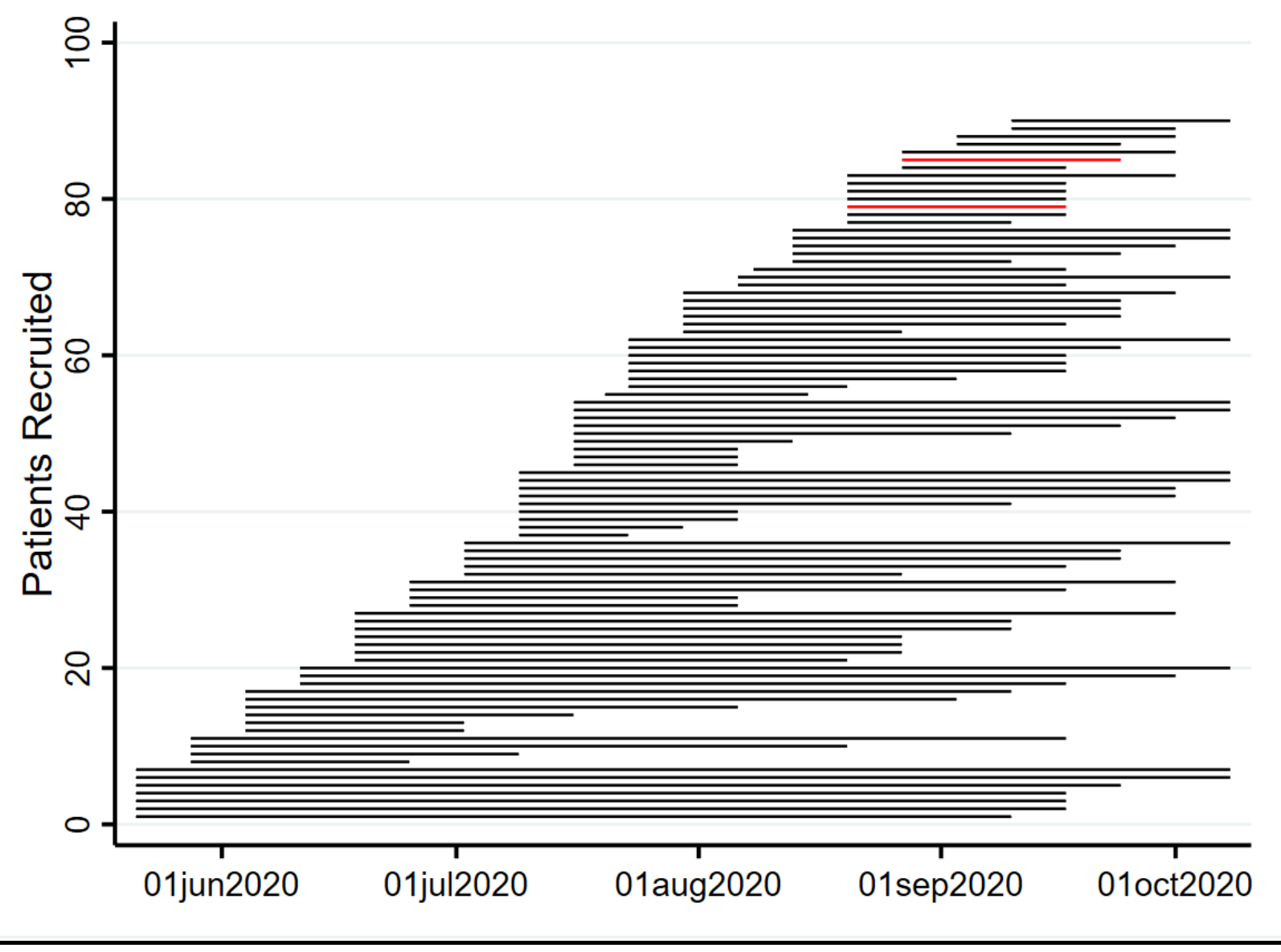

Figure 1. Swimmers Plot: Time under observation for seroconversion in patients with at

least one serial blood draw ( $\mathrm{n}=\mathbf{9 0}$ ): Each patient's time under observation is represented by a horizontal bar, which spans the time from first to final blood draw. Black represents seronegative; red represents seropositive (detectable anti-SARS-CoV-2 IgG or IgM antibody). No patients who were initially seronegative became seropositive on subsequent blood draw. 
medRxiv preprint doi: https://doi.org/10.1101/2021.01.15.21249810; this version posted January 16, 2021. The copyright holder for this preprint (which was not certified by peer review) is the author/funder, who has granted medRxiv a license to display the preprint in perpetuity.

Table 1. Study Subjects

\begin{tabular}{|c|c|}
\hline Characteristic & Number (\%), $\mathrm{N}=124$ \\
\hline Age, years (IQR) & $62(53-69)$ \\
\hline Female Sex & $64(52 \%)$ \\
\hline \multicolumn{2}{|l|}{ Race } \\
\hline White & $104(84 \%)$ \\
\hline Black or African American & $10(8 \%)$ \\
\hline Asian & $4(3 \%)$ \\
\hline Multiple Races & $1(1 \%)$ \\
\hline Other/Unknown & $5(4 \%)$ \\
\hline Hispanic Ethnicity & $2(2 \%)$ \\
\hline \multicolumn{2}{|l|}{ ECOG performance status } \\
\hline 0 & $63(51 \%)$ \\
\hline 1 & $44(35 \%)$ \\
\hline 2 & $10(8 \%)$ \\
\hline 3 & $7(6 \%)$ \\
\hline \multicolumn{2}{|l|}{ Smoking history } \\
\hline Never & $61(49 \%)$ \\
\hline Prior & $54(44 \%)$ \\
\hline Current & $9(7 \%)$ \\
\hline Charlson Comorbidity Index, median (IQR) & $8(6-9)$ \\
\hline BMI, median (IQR) & $27(23-32)$ \\
\hline \multicolumn{2}{|l|}{ Primary Cancer Diagnosis } \\
\hline Lung & $28(23 \%)$ \\
\hline Breast & $22(18 \%)$ \\
\hline Melanoma & $19(15 \%)$ \\
\hline Kidney & $17(14 \%)$ \\
\hline Colon/Rectum & $13(11 \%)$ \\
\hline Pancreas & $10(8 \%)$ \\
\hline Prostate & $4(3 \%)$ \\
\hline Esophagus or Gastric & $4(3 \%)$ \\
\hline Othera & $7(6 \%)$ \\
\hline \multicolumn{2}{|l|}{ Stage of cancer } \\
\hline 1 & $9(7 \%)$ \\
\hline II & $7(6 \%)$ \\
\hline III & $35(28 \%)$ \\
\hline IV & $71(57 \%)$ \\
\hline Unknown & $2(2 \%)$ \\
\hline Number of lines of systemic therapy, median (IQR) & $2(1-4)$ \\
\hline \multicolumn{2}{|l|}{ Cancer Therapy Type } \\
\hline Chemotherapy & $62(50 \%)$ \\
\hline Immunotherapy & $54(44 \%)$ \\
\hline Chemoimmunotherapy & $8(7 \%)$ \\
\hline Number of visits since March 1, median (IQR) & $13(9-18)$ \\
\hline Number of therapy cycles since March 1, median (IQR) & $7(5-10)$ \\
\hline Neutropenic $(A N C<500)$ since March 1 & $3(2 \%)$ \\
\hline Leukopenic $(\mathrm{WBC}<\mathrm{LLN})$ since March 1 & $46(37 \%)$ \\
\hline \multicolumn{2}{|l|}{ Number of blood draws for SARS-CoV-2 antibodies } \\
\hline 2 & $90(73 \%)$ \\
\hline 3 & $51(41 \%)$ \\
\hline 4 & $21(17 \%)$ \\
\hline 5 & $8(6 \%)$ \\
\hline
\end{tabular}

aOther cancers included ovary $(n=1)$, pharynx $(n=1)$, thymus $(n=1)$, and unknown primary $(n=4)$.

Abbreviations: IQR, interquartile range; ECOG, Eastern Cooperative Oncology Group; BMI, body mass index; ANC, absolute neutrophil count; WBC, white blood cell; LLN, lower limit of normal 